\title{
SARS-CoV-2 Sequence Characteristics of COVID-19 Persistence and Reinfection
}

3 Manish C. Choudhary ${ }^{1^{*}}$, Charles R. Crain ${ }^{1,2^{*}}$, Xueting Qiu ${ }^{3}$, William Hanage ${ }^{3}$, Jonathan Z. $\mathrm{Li}^{1}$

$5 \quad$ 'Brigham and Women's Hospital, Harvard Medical School, Boston, MA, USA

$6 \quad{ }^{2}$ Northeastern University, Boston, MA, USA

$7 \quad{ }^{3}$ Center for Communicable Disease Dynamics, Department of Epidemiology, Harvard T.H. Chan

8 School of Public Health, Boston, MA, USA

$9 \quad{ }^{*}$ Authors contributed equally

10

11 Key words: SARS-CoV-2, persistent COVID-19, reinfection, sequence analysis,

12 immunosuppression

Running title: COVID-19 Persistence and Reinfection

Corresponding Author:

17 Jonathan Li, MD

18 Brigham and Women's Hospital

19 Harvard Medical School

20 Cambridge, Massachusetts, USA

21 li@@bwh.harvard.edu

22 Alternate corresponding author:

23 Manish C. Choudhary, PhD

24 Brigham and Women's Hospital

25 Harvard Medical School

26 Cambridge, Massachusetts, USA 
medRxiv preprint doi: https://doi.org/10.1101/2021.03.02.21252750; this version posted April 17, 2021. The copyright holder for this preprint (which was not certified by peer review) is the author/funder, who has granted medRxiv a license to display the preprint in perpetuity. It is made available under a CC-BY-NC-ND 4.0 International license .

27 mchoudhary@bwh.harvard.edu

28

29 Summary:

30 Reinfecting SARS-CoV-2 viral genomes largely mirror contemporaneous circulating sequences

31 in that geographic region, while persistent COVID-19 has been largely described in

32 immunosuppressed individuals and is associated with accelerated viral evolution.

33

34 Funding: This study was funded in part by the NIH grant 106701.

35

36

Disclosures:

37 Dr. Li has consulted for Abbvie. 
medRxiv preprint doi: https://doi.org/10.1101/2021.03.02.21252750; this version posted April 17, 2021. The copyright holder for this preprint (which was not certified by peer review) is the author/funder, who has granted medRxiv a license to display the preprint in perpetuity.

It is made available under a CC-BY-NC-ND 4.0 International license .

\section{ABSTRACT}

Background. Both SARS-CoV-2 reinfection and persistent infection have been reported, but sequence characteristics in these scenarios have not been described. We assessed published cases of SARS-CoV-2 reinfection and persistence, characterizing the hallmarks of reinfecting sequences and the rate of viral evolution in persistent infection.

Methods. A systematic review of PubMed was conducted to identify cases of SARS-CoV-2 reinfection and persistence with available sequences. Nucleotide and amino acid changes in the reinfecting sequence were compared to both the initial and contemporaneous community variants. Time-measured phylogenetic reconstruction was performed to compare intra-host viral evolution in persistent SARS-CoV-2 to community-driven evolution.

Results. Twenty reinfection and nine persistent infection cases were identified. Reports of reinfection cases spanned a broad distribution of ages, baseline health status, reinfection severity, and occurred as early as 1.5 months or $>8$ months after the initial infection. The reinfecting viral sequences had a median of 17.5 nucleotide changes with enrichment in the ORF8 and $\mathrm{N}$ genes. The number of changes did not differ by the severity of reinfection and reinfecting variants were similar to the contemporaneous sequences circulating in the community. Patients with persistent COVID-19 demonstrated more rapid accumulation of sequence changes than seen with community-driven evolution with continued evolution during convalescent plasma or monoclonal antibody treatment.

Conclusions. Reinfecting SARS-CoV-2 viral genomes largely mirror contemporaneous circulating sequences in that geographic region, while persistent COVID-19 has been largely described in immunosuppressed individuals and is associated with accelerated viral evolution. 
medRxiv preprint doi: https://doi.org/10.1101/2021.03.02.21252750; this version posted April 17, 2021. The copyright holder for this preprint (which was not certified by peer review) is the author/funder, who has granted medRxiv a license to display the preprint in perpetuity.

It is made available under a CC-BY-NC-ND 4.0 International license .

\section{BACKGROUND}

62 After resolution of coronavirus disease 2019 (COVID-19) following SARS-CoV-2 infection, 63 antibodies against SARS-CoV-2 persist in the majority of patients for 6 months or more [1].

64 Despite this, there have now been a number of reports of COVID-19 reinfection, spanning a 65 broad range of age groups, time frames, and disease severity [2-7]. There remains a great deal 66 of uncertainty over the viral characteristics of reinfection cases, including the degree of 67 sequence heterogeneity and the location of new mutations between the initial and reinfecting 68 variants, if any. In addition, the diagnosis of COVID-19 reinfection has been complicated by the 69 increasing reports of persistent COVID-19 infection, especially in immunosuppressed 70 individuals. Like reinfection cases, persistent COVID-19 can also span the range of disease

71 severity, from asymptomatic to severe disease, and recurrent symptoms can last for months [8-

72 11]. Differentiating between persistence and reinfection can be challenging, and little is known 73 about differences in the location and quantity of SARS-CoV-2 mutations in these scenarios. We

74 performed an analysis of SARS-CoV-2 sequences from published cases of COVID-19

75 reinfection and persistence, characterizing the hallmarks of reinfecting sequences and the rate 76 of viral evolution in persistent infection. 
medRxiv preprint doi: https://doi.org/10.1101/2021.03.02.21252750; this version posted April 17, 2021. The copyright holder for this preprint (which was not certified by peer review) is the author/funder, who has granted medRxiv a license to display the preprint in perpetuity.

It is made available under a CC-BY-NC-ND 4.0 International license .

\section{METHODS}

\section{Data search and selection criteria}

81 We conducted a systematic literature review in PubMed through March 8, 2021 for cases of

82 persistent COVID-19 using the search term "((covid or sars-CoV-2) AND (persistent or

83 persistence or prolonged)) AND (sequence or evolution)". A search for COVID-19 reinfection

84 reports was made using the terms "(covid or sars-CoV-2) AND (reinfection)". Both peer-

85 reviewed and preprint results were evaluated. We used the Preferred Reporting Items for

86 Systematic Reviews and Meta-Analyses (PRISMA) for reviewing literature and for reporting

87 search results. Additional preprints that appeared through Google search and that met our criteria were also included. For cases of reinfection, papers were included if the authors described it as a case of reinfection diagnosed $>30$ days after the initial infection and if whole genome SARS-CoV-2 sequences or sites of mutations relative to a reference sequence

91 (e.g., Wuhan-Hu-1) from both infection time-points were available. Of the 291 results from the

92 search, 14 articles met the inclusion criteria and were included in the present report along with 2 additional preprints that were identified (Supplemental Figure 1A).

Persistent cases were included if the authors described it as a case of persistent

COVID-19 infection and if longitudinal whole genome SARS-CoV-2 sequences were available. The search returned 129 results, 7 of which met the inclusion criteria and were

97 included in the present report along with one other preprint (Supplemental Figure 1B). Only sequences obtained directly from patient respiratory tract samples were included in our analysis to exclude the possibility of sequence changes during the ex vivo culture process.

100 Three cases were excluded due to uncertainty in their classification as either reinfection or 101 persistent infection cases (Supplemental Methods, Supplemental Table 1, Supplemental 102 Figure 2). 
medRxiv preprint doi: https://doi.org/10.1101/2021.03.02.21252750; this version posted April 17, 2021. The copyright holder for this preprint (which was not certified by peer review) is the author/funder, who has granted medRxiv a license to display the preprint in perpetuity.

It is made available under a CC-BY-NC-ND 4.0 International license .

mutations

using

NextClade

(https://github.com/sanger-pathogens/snp-

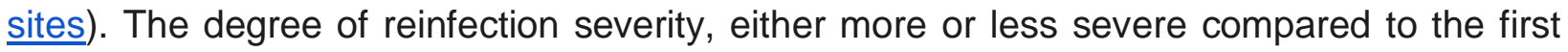
by comparing symptoms, duration of illness, and hospitalization status between both episodes.

\section{Sequencing dataset compilation and phylogenetic tree construction}

111 The sequencing dataset contained a total of 262 globally representative SARS-CoV-2 genomes

112 selected from GISAID and sequences from the reinfection and persistence cases (Supplemental

113 Methods; Supplemental Data 1). The sampled sequences were chosen to be representative of

114 global sequence diversity throughout the time course of the pandemic. Sequences of variants of

115 concern B.1.1.7 and B.1.351 were also included. Nucleotide sequence alignment was

116 performed using MAFFT (Multiple Alignment using Fast Fourier Transform) [12]. Best-fit

117 nucleotide substitution was calculated using model selection followed by maximum likelihood

118 (ML) phylogenetic tree construction using IQ-Tree with 1000-bootstrap replicates [12].

\section{Mutation analysis}

121 For reinfection cases, mutations were determined in two ways. First, nucleotide and amino acid

122 changes were identified for the reinfection sequences relative to the first infection sequence.

123 The frequency of nucleotide or amino acid changes within each gene was compared to the

124 frequency of changes in the remainder of the genome by Fisher's exact tests with a Bonferroni

125 correction (for multiple comparisons). The relationship between disease severity and number of

126 nucleotide or amino acid changes in the genome was assessed using a Mann-Whitney test.

127 Second, to identify unique characteristics of reinfecting viruses, each of the first and reinfection 
medRxiv preprint doi: https://doi.org/10.1101/2021.03.02.21252750; this version posted April 17, 2021. The copyright holder for this preprint (which was not certified by peer review) is the author/funder, who has granted medRxiv a license to display the preprint in perpetuity.

It is made available under a CC-BY-NC-ND 4.0 International license .

sequences were compared to circulating sequences in the community as defined by the same NextStrain clade sampled within one month obtained from the same geographic location uploaded to GISAID (https://www.gisaid.org/; Supplemental Table 2, Supplemental Methods, Supplemental Data 2). Rare mutations were determined as polymorphisms that were present only in the reinfecting sequence (not the initial variant) and found in less than $1 \%$ of contemporaneous community sequences. Mutation locations are graphically represented in Circos plots [13].

For persistent infections, sequence changes were assessed at two time intervals: before or after convalescent plasma or monoclonal antibody treatment. Sequences sampled before convalescent plasma or antibody treatment were compared to the first sequence sampled. For sequences sampled after convalescent plasma or antibody treatment, sequence changes (both nucleotide and amino acid) were determined relative to the last pre-treatment sequence. Linear regression was used to estimate the rate of viral changes between two intervals. The slope of the trendline was compared to the latest global clock rate (March 29, 2021) as estimated by NextStrain (https://nextstrain.org/ncov/global/).

\section{Time-measured phylogenetic analysis}

The temporal signal of the ML tree was examined in TempEst [14] regressing on root-to-tip divergence, and outliers were inspected in the distribution of residuals. A high degree of clocklike behavior in the whole dataset was observed $\left(R^{2}=0.721\right)$ in root-to-tip regression analysis with the slope rate as $8.26 \mathrm{E}-4$ and the rough ancestral time of the sample was calculated as 2019.84. This suggests that the whole dataset has a realistic temporal signal and it is appropriate for an estimation of temporal parameters. No outliers were found in this sample. To further examine the temporal signal in the sequences from persistent patients (especially these with $>2$ sequences), separate root-to-tip regression analysis also supported temporal signal for a time-measured phylogeny. To compare the evolutionary rates between the reported persistent 
medRxiv preprint doi: https://doi.org/10.1101/2021.03.02.21252750; this version posted April 17, 2021. The copyright holder for this preprint (which was not certified by peer review) is the author/funder, who has granted medRxiv a license to display the preprint in perpetuity.

It is made available under a CC-BY-NC-ND 4.0 International license .

154 infections and the general population infections, time-measured phylogenetic reconstruction 155 was conducted in Bayesian Evolutionary Analysis Sampling Trees (BEAST) v1.10.4 [15]. Nine 156 partitions, including eight persistent patients and the global sequences, were used as separate 157 groups of taxa, to estimate separate evolutionary rates. Due to large uncertainties with small 158 samples, persistent patients with only two viral sequences were excluded from this analysis. A 159 general time reversible (GTR) model was applied with gamma-distributed rate variations among 160 sites. A lognormal relaxed molecular clock was used with an initial mean of 0.0008 and a 161 uniform prior ranging from 0.0 to 1.0. A logistic growth tree prior was applied. Four independent 162 Bayesian Markov Chain Monte Carlo (MCMC) chains of 100 million generations were performed 163 with a sampling step every 10,000 generations to yield 10,000 trees per run. To ensure a 164 sufficient effective sample size ESS $>200$, the convergence of three runs was diagnosed in 165 Tracer v 1.7.1 (http://tree.bio.ed.ac.uk/software/tracer/) for all parameters. LogCombiner v1.10.4 166 as part of the BEAST software package was used to combine the multiple runs to generate log 167 and tree files after appropriate removal of the burn-in from each MCMC chain. The comparison 168 of the evolutionary rates from the combined log file is analyzed and visualized in $R$ v4.0.2 169 (https://www.r-project.org/).

\section{Statistical analysis}

172 Nonparametric Wilcoxon rank sum or matched pairs signed rank tests were used to compare 173 the number of amino acid changes between sequences. Statistical analyses were performed 174 using GraphPad Prism 9 (GraphPad Software, San Diego, CA). 
medRxiv preprint doi: https://doi.org/10.1101/2021.03.02.21252750; this version posted April 17, 2021. The copyright holder for this preprint (which was not certified by peer review) is the author/funder, who has granted medRxiv a license to display the preprint in perpetuity.

It is made available under a CC-BY-NC-ND 4.0 International license .

175

176

177

178

179

180

181

182

183

184

185

186

187

188

189

190

191

192

193

194

195

\section{RESULTS}

\section{Sequence analysis of reinfection cases}

A total of twenty cases from sixteen reports were included in this analysis (Table 1) [2-7, 16-25]. A broad range of age groups were represented and $90 \%$ were under the age of 70 years. Most $(80 \%)$ of the cases had no reported comorbidities and while one patient had diabetes and endstage renal disease, none had high-level immunosuppression. The interval between diagnosis of the first infection and the second infection ranged from 44 days to 282 days with a median of 113.5 days. Five patients had more severe illness during the second infection, while six had less severe symptoms on reinfection, including two who were asymptomatic on reinfection. Two cases were asymptomatic in both infections, five cases reported the same severity for both infections and no information on infection severity was available for two cases (Table 1). Six cases reported reinfection with a virus from the same clade.

Phylogenetic analysis demonstrated distinct branching for the two sequences in each of the reinfection cases, corroborating results discussed in the original reports (Figure 1). We compared nucleotide and amino acid changes in the reinfecting viral sequence compared to the initial sequence and found a median of 17.5 nucleotide changes (range 9-37) and 9 amino-acid changes (range 6-24) compared to the original sequence (Figure 2A). The nucleotide changes between the initial and reinfecting sequences were distributed across the SARS-CoV-2 genome, with significantly higher frequencies of changes in ORF8 $(P<0.001)$ and $N(P=0.001)$ (Figure 2B). A similar pattern was observed with amino acid changes (Supplemental Figure 3A). All but two reinfection cases had at least one substitution or deletion in the $S$ gene (Supplemental Table 3). Next, we assessed whether reinfection with a more divergent second virus resulted in more severe disease. We found no significant differences in the number of nucleotide or amino acid changes in the reinfecting virus compared to the original viral variant when categorized by the severity of the reinfection (Figure 2C; Supplemental Figure 3B). Both the initial and reinfecting SARS-CoV-2 variants were similar to the sequences circulating in the community at 
medRxiv preprint doi: https://doi.org/10.1101/2021.03.02.21252750; this version posted April 17, 2021. The copyright holder for this preprint (which was not certified by peer review) is the author/funder, who has granted medRxiv a license to display the preprint in perpetuity.

It is made available under a CC-BY-NC-ND 4.0 International license .

201 the time of reinfection. The initial infecting variant harbored a median of only 2 rare nucleotide

202 mutations compared to contemporaneous circulating variants in the community and the

203 reinfecting variant contained a median of only 1 rare nucleotide mutation (Figure 2D-E;

204 Supplemental Figure 3C).

205

206

\section{Sequence analysis of persistent COVID-19 cases}

207 A total of nine cases from seven reports describing persistent infection were retrieved from our

208 literature search. Of these nine cases, all but one had B cell immunodeficiency [8-10, 26-29].

209 Four were treated with B cell-depleting therapy for lymphoma or autoimmune disorders, while

210 four had B cell lymphomas treated with chemotherapy (Table 2). One patient had advanced HIV

211 infection with a CD4+ count of 0 cells $/ \mathrm{mm}^{3}$ and diminished CD19+ cell counts. The median

212 length of infection was 154 days and $33 \%$ of the cases ended in death. One patient had

213 asymptomatic disease throughout [9]. Four patients were treated with convalescent plasma at

214 least once during their illness [9, 10, 26, 28], and one patient was treated with the monoclonal

215 antibodies casirivimab and imdevimab [8].

216 Phylogenetic analysis revealed that, for each of the nine patients, sequences formed a

217 distinct cluster, confirming what was found in the original reports (Figure 1). New mutations

218 emerging over time were detected in all of the persistent COVID-19 patients with further

219 changes identified after treatment with convalescent plasma or monoclonal antibodies

220 (Supplemental Figure 4). Mutations occurred with significantly higher frequency in $S(P<0.001)$

221 and ORF7a $(P=0.02)$ and lower frequency in ORF1a $(P=0.02)$ (Figure 3A; Supplemental Figure

$2225 \mathrm{~A})$. The rate of viral evolution was plotted for each patient both for the interval before and after

223 convalescent plasma/antibody treatment. Before antiviral treatment, the rate of sequence

224 changes over time appeared faster than the NextStrain estimate for the global rate of SARS-

225 CoV-2 evolution (dotted purple line) (Figure 3B; Supplemental Figure 5B). Treatment with 
medRxiv preprint doi: https://doi.org/10.1101/2021.03.02.21252750; this version posted April 17, 2021. The copyright holder for this preprint (which was not certified by peer review) is the author/funder, who has granted medRxiv a license to display the preprint in perpetuity. It is made available under a CC-BY-NC-ND 4.0 International license .

226 convalescent plasma or antibody cocktail treatment was insufficient to halt intra-host viral 227 evolution (Figure 3C; Supplemental Figure 5C).

228 We also performed time-measured phylogenetic reconstruction with the pre-treatment 229 persistent sequences to compare the rate of intra-host viral evolution in persistent COVID-19 to 230 the rate of community-driven evolution. This analysis provided further evidence that SARS-CoV2312 evolution appeared faster in these persistent infection individuals compared to the rate in the 232 general public population, though substantial uncertainties are shown in these estimates given 233 the limited sequence sampling in each patient (Figure 3D; Supplemental Table 4). 
medRxiv preprint doi: https://doi.org/10.1101/2021.03.02.21252750; this version posted April 17, 2021. The copyright holder for this preprint (which was not certified by peer review) is the author/funder, who has granted medRxiv a license to display the preprint in perpetuity. It is made available under a CC-BY-NC-ND 4.0 International license .

\section{DISCUSSION}

We conducted a systematic review and pooled analysis of sequences from reports of COVID-19 reinfection and persistent infection. Reports of reinfection cases demonstrate a wide range of situations: spanning a broad distribution of ages, baseline health status and reinfection severity compared to the initial infection. Reinfection occurred as early as 1.5 months or $>8$ months after the initial infection. Common explanations for the presence of reinfection involves either waning SARS-CoV-2 antibodies or the presence of viral escape mutations [30,31]. While most cases of SARS-CoV-2 reinfection did involve infection with a different clade (including the variants of concern B.1.1.7 and P.1), it is noteworthy that mutations were identified throughout the genomes and the frequency of mutations within the $S$ gene was not elevated relative to the rest of the genome. In addition, individuals with more severe reinfections did not have significantly greater frequency of S gene mutations. Interestingly, the genes with the highest frequency of mutations was ORF8 and N. ORF8 is a rapidly evolving accessory protein that may antagonize host immune function [32] while the nucleocapsid is a vital structural protein that also serves as a target for both humoral and cell-mediated immune responses [33]. Finally, the presence of rare mutations was uncommon in the reinfecting virus, which largely mirrored the contemporaneously circulating variants in the region of infection. However, the reinfecting variants generally contained a substantial number of mutations compared to the initial variant, including frequent changes in the $S$ gene, and additional studies are needed to assess whether these changes may have contributed to the risk of repeat infection.

While the number of immunosuppressed individuals with available sequences remains limited, the results suggest that the rate of viral evolution (measuring both synonymous and non-synonymous changes), is accelerated within immunosuppressed individuals. In addition, treatment with convalescent plasma or monoclonal antibody cocktails was insufficient to fully halt viral evolution and the emergence of viral escape with treatment has been documented [26, 34]. Mutations associated with immune escape and/or more efficient replication kinetics, 
medRxiv preprint doi: https://doi.org/10.1101/2021.03.02.21252750; this version posted April 17, 2021. The copyright holder for this preprint (which was not certified by peer review) is the author/funder, who has granted medRxiv a license to display the preprint in perpetuity. It is made available under a CC-BY-NC-ND 4.0 International license.

261 including E484K, S494P, N501Y and N-terminal spike deletions, have been observed in both

262 immunosuppressed individuals and the novel variants of concern $[35,36]$. The results raise the

263 possibility that novel variants, including those harboring escape mutations against current

264 treatments, could arise from immunosuppressed individuals and suggest that

265 immunosuppressed individuals should be a focus of public health efforts. Amongst the current

266 reports of persistent COVID-19, B-cell dysfunction appears to be a common thread, including in

267 reports that were not included in this analysis due to a lack of available full-length sequences

268 [37-41]. It is important to note, though, that $\mathrm{T}$ cell function may also play a role in protection

269 against SARS-CoV-2 [42] and a subset of these patients also included concurrent suppression

270 of other aspects of the immune response. Additional studies are needed to fully define the type

271 and intensity of immunosuppression that would place patients at greatest risk of persistent

272 COVID-19.

273

Two factors generally differentiated between reinfection and persistent infection

274 scenarios: first, reinfections have so far been largely described in immunocompetent individuals

275 while the majority of persistent COVID cases have been in immunosuppressed patients.

276 Secondly, phylogenetic analysis can generally differentiate between reinfection and persistent

277 infection, especially in cases where persistent infection allowed the longitudinal collection of $>2$

278 sequences. However, given the slow rate of SARS-CoV-2 evolution and limited viral diversity

279 [43], it can be challenging to differentiate between reinfection and persistent infection, especially

280 in situations with limited sampling and/or duration between samples.

A limitation of this work is that it relies on case reports, which can be influenced by

282 publication bias and limits our statistical power. However, to date, there have been no

283 systematic, large-scale sequence-based studies of COVID-19 reinfection or persistent

284 infections. This is partly due to the rarity of these types of cases and that initial infecting

285 sequences are frequently unavailable for comparison with reinfecting or persistently infecting

286 variants. Overall, our results demonstrate the need to further explore factors that increase the 
medRxiv preprint doi: https://doi.org/10.1101/2021.03.02.21252750; this version posted April 17, 2021. The copyright holder for this preprint (which was not certified by peer review) is the author/funder, who has granted medRxiv a license to display the preprint in perpetuity. It is made available under a CC-BY-NC-ND 4.0 International license.

287 risk of breakthrough reinfections and persistent COVID-19. This line of investigation will have

288 important implications on the durability of current available vaccines and for preventing the rise

289 of novel variants.

290

291

292 Acknowledgements

293 We thank Jeremy Luban and Ronald Bosch for their feedback and discussion. 
medRxiv preprint doi: https://doi.org/10.1101/2021.03.02.21252750; this version posted April 17, 2021. The copyright holder for this preprint (which was not certified by peer review) is the author/funder, who has granted medRxiv a license to display the preprint in perpetuity.

It is made available under a CC-BY-NC-ND 4.0 International license .

\section{REFERENCES}

1. Dan JM, Mateus J, Kato Y, et al. Immunological memory to SARS-CoV-2 assessed for up to 8 months after infection. Science 2021.

2. Van Elslande J, Vermeersch P, Vandervoort K, et al. Symptomatic SARS-CoV-2 reinfection by a phylogenetically distinct strain. Clin Infect Dis 2020.

3. To KK, Hung IF, Ip JD, et al. COVID-19 re-infection by a phylogenetically distinct SARScoronavirus-2 strain confirmed by whole genome sequencing. Clin Infect Dis 2020.

4. Tillett RL, Sevinsky JR, Hartley PD, et al. Genomic evidence for reinfection with SARS-CoV-2: a case study. Lancet Infect Dis 2021; 21(1): 52-8.

5. Selhorst $P$, Van lerssel S, Michiels J, et al. Symptomatic SARS-CoV-2 reinfection of a health care worker in a Belgian nosocomial outbreak despite primary neutralizing antibody response. Clin Infect Dis 2020.

6. Harrington D, Kele B, Pereira S, et al. Confirmed Reinfection with SARS-CoV-2 Variant VOC202012/01. Clin Infect Dis 2021.

7. Goldman JD, Wang K, Roltgen K, et al. Reinfection with SARS-CoV-2 and Failure of Humoral Immunity: a case report. medRxiv 2020.

8. Choi B, Choudhary MC, Regan J, et al. Persistence and Evolution of SARS-CoV-2 in an Immunocompromised Host. N Engl J Med 2020; 383(23): 2291-3.

9. Avanzato VA, Matson MJ, Seifert SN, et al. Case Study: Prolonged Infectious SARS-CoV-2 Shedding from an Asymptomatic Immunocompromised Individual with Cancer. Cell 2020; 183(7): 1901-12 e9.

10. Baang JH, Smith C, Mirabelli C, et al. Prolonged Severe Acute Respiratory Syndrome Coronavirus 2 Replication in an Immunocompromised Patient. J Infect Dis 2021; 223(1): 23-7.

11. Kemp SA, Collier DA, Datir R, et al. Neutralising antibodies in Spike mediated SARS-CoV-2 adaptation. medRxiv 2020.

12. Trifinopoulos J, Nguyen LT, von Haeseler A, Minh BQ. W-IQ-TREE: a fast online phylogenetic tool for maximum likelihood analysis. Nucleic Acids Res 2016; 44(W1): W232-5.

13. Krzywinski MI, Schein JE, Birol I, et al. Circos: An information aesthetic for comparative genomics. Genome Research 2009.

14. Rambaut A, Lam T, Max Carvalho L, Pybus OG. Exploring the temporal structure of heterochronous sequences using TempEst (formerly Path-O-Gen). Virus Evol 2016; 2(1): vew007.

15. Drummond AJ, Suchard MA, Xie D, Rambaut A. Bayesian phylogenetics with BEAUti and the BEAST 1.7. Mol Biol Evol 2012; 29(8): 1969-73.

16. Prado-Vivar B, Becerra-Wong M, Guadalupe JJ, et al. A case of SARS-CoV-2 reinfection in Ecuador. Lancet Infect Dis 2020.

17. Resende PC, de Vasconcelos RHT, Arantes I, et al. Spike E484K mutation in the first SARS-CoV-2 reinfection case confirmed in Brazil. Virologica 2021.

18. Colson P, Finaud M, Levy N, Lagier JC, Raoult D. Evidence of SARS-CoV-2 re-infection with a different genotype. J Infect 2020.

19. Nonaka CKV, Franco MM, Graf T, et al. Genomic Evidence of a Sars-Cov-2 Reinfection Case With E484K Spike Mutation in Brazil. Preprintsorg 2021.

20. Gupta V, Bhoyar RC, Jain A, et al. Asymptomatic reinfection in two healthcare workers from India with genetically distinct SARS-CoV-2. Clin Infect Dis 2020.

21. Abu-Raddad $\mathrm{L}$, Chemaitelly $\mathrm{H}$, Malek JA, et al. Assessment of the risk of SARS-CoV-2 reinfection in an intense re-exposure setting. Clin Infect Dis 2020.

22. Naveca FG, da Costa C, Nascimento V, et al. Three SARS-CoV-2 reinfection cases by the new Variant of Concern (VOC) P.1/501Y.V3. Research Square 2021. 
medRxiv preprint doi: https://doi.org/10.1101/2021.03.02.21252750; this version posted April 17, 2021. The copyright holder for this preprint (which was not certified by peer review) is the author/funder, who has granted medRxiv a license to display the preprint in perpetuity.

It is made available under a CC-BY-NC-ND 4.0 International license .

23. Vetter $\mathrm{P}, \mathrm{Cordey} \mathrm{S}$, Schibler $\mathrm{M}$, et al. Clinical, virologic and immunologic features of a mild case of SARS-CoV-2 reinfection. Clin Microbiol Infect 2021.

24. Kulkarni O, Narreddy S, Zaveri L, Kalal IG, Tallapaka KB, Sowpati DT. Evidence of SARS-CoV-2 reinfection without mutations in Spike protein. Clin Infect Dis 2021.

25. Adrielle Dos Santos L, Filho PGG, Silva AMF, et al. Recurrent COVID-19 including evidence of reinfection and enhanced severity in thirty Brazilian healthcare workers. J Infect 2021; 82(3): 399-406.

26. Kemp SA, Collier DA, Datir RP, et al. SARS-CoV-2 evolution during treatment of chronic infection. Nature 2021.

27. Tarhini H, Recoing A, Bridier-Nahmias A, et al. Long term SARS-CoV-2 infectiousness among three immunocompromised patients: from prolonged viral shedding to SARS-CoV-2 superinfection. J Infect Dis 2021.

28. Truong TT, Ryutov A, Pandey U, et al. Persistent SARS-CoV-2 infection and increasing viral variants in children and young adults with impaired humoral immunity. medRxiv 2021.

29. Borges $V$, Isidro J, Cunha $M$, et al. Long-term evolution of SARS-CoV-2 in an immunocompromised patient with non-Hodgkin lymphoma. Virological 2021.

30. Wibmer CK, Ayres F, Hermanus T, et al. SARS-CoV-2 501Y.V2 escapes neutralization by South African COVID-19 donor plasma. bioRxiv 2021.

31. Weisblum $Y$, Schmidt F, Zhang F, et al. Escape from neutralizing antibodies by SARS-CoV-2 spike protein variants. Elife 2020; 9.

32. Flower TG, Buffalo CZ, Hooy RM, Allaire M, Ren X, Hurley JH. Structure of SARS-CoV-2 ORF8, a rapidly evolving coronavirus protein implicated in immune evasion. bioRxiv 2020.

33. Nelde A, Bilich T, Heitmann JS, et al. SARS-CoV-2-derived peptides define heterologous and COVID-19-induced T cell recognition. Nat Immunol 2021; 22(1): 74-85.

34. Starr TN, Greaney AJ, Addetia A, et al. Prospective mapping of viral mutations that escape antibodies used to treat COVID-19. Science 2021; 371(6531): 850-4.

35. Volz E, Mishra S, Chand M, et al. Assessing transmissibility of SARS-CoV-2 lineage B.1.1.7 in England. Nature 2021.

36. Tegally $\mathrm{H}$, Wilkinson $\mathrm{E}$, Giovanetti $\mathrm{M}$, et al. Detection of a SARS-CoV-2 variant of concern in South Africa. Nature 2021.

37. Camprubi-Ferrer D, Gaya A, Marcos MA, et al. Persistent replication of SARS-CoV-2 in a severely immunocompromised treated with several courses of remdesivir. Int J Infect Dis 2020.

38. Hensley MK, Bain WG, Jacobs J, et al. Intractable COVID-19 and Prolonged SARS-CoV-2 Replication in a CAR-T-cell Therapy Recipient: A Case Study. Clin Infect Dis 2021.

39. Martinot $M$, Jary A, Fafi-Kremer $S$, et al. Remdesivir failure with SARS-CoV-2 RNA-dependent RNA-polymerase mutation in a B-cell immunodeficient patient with protracted Covid-19. Clin Infect Dis 2020.

40. Helleberg M, Niemann CU, Moestrup KS, et al. Persistent COVID-19 in an Immunocompromised Patient Temporarily Responsive to Two Courses of Remdesivir Therapy. J Infect Dis 2020; 222(7): 1103-7.

41. Sepulcri C, Dentone C, Mikulska M, et al. The longest persistence of viable SARS-CoV-2 with recurrence of viremia and relapsing symptomatic COVID-19 in an immunocompromised patient - a case study. medRxiv 2021: 2021.01.23.21249554.

42. McMahan K, Yu J, Mercado NB, et al. Correlates of protection against SARS-CoV-2 in rhesus macaques. Nature 2020.

43. Rausch JW, Capoferri AA, Katusiime MG, Patro SC, Kearney MF. Low genetic diversity may be an Achilles heel of SARS-CoV-2. Proc Natl Acad Sci U S A 2020; 117(40): 24614-6. 
medRxiv preprint doi: https://doi.org/10.1101/2021.03.02.21252750; this version posted April 17, 2021. The copyright holder for this preprint (which was not certified by peer review) is the author/funder, who has granted medRxiv a license to display the preprint in perpetuity.

It is made available under a CC-BY-NC-ND 4.0 International license. 
medRxiv preprint doi: https://doi.org/10.1101/2021.03.02.21252750; this version posted April 17, 2021. The copyright holder for this preprint (which was not certified by peer review) is the author/funder, who has granted medRxiv a license to display the preprint in perpetuity. It is made available under a CC-BY-NC-ND 4.0 International license .

Figure 1. Maximum-likelihood phylogenetic tree of sequences from persistent COVID-19 cases (Pe1-Pe7), COVID-19 reinfection cases (Re1-Re16), the variants of concern B.1.1.7 and B.1.351, and globally sampled sequences from GISAID.

Figure 2. Comparison of viral sequences from reinfection cases. (A) Circos plot showing location of nucleotide changes in the reinfecting sequence relative to the initial infection sequence for each of the 20 cases. Inner ring indicates nucleotide position in kilobases. Synonymous changes are in green, nonsynonymous changes in orange, deletions in black. (B) Nucleotide (NT) substitution frequency pooled across all reinfection cases for each SARS-CoV2 gene. Dashed line indicates global substitution frequency across the whole genome. Substitution frequency for each gene was compared to the substitution frequency in the rest of the genome using a Fisher's exact test. P-values were corrected for multiple comparisons using the Bonferroni correction. ${ }^{*}<0.05,{ }^{* *}<0.01$ and ${ }^{* * *}<0.001$ (C) Nucleotide changes in the second infection relative to the first infection by clinical disease severity. Mutations shown for the whole genome and $\mathrm{S}$ gene. $\mathrm{P}=0.67$, Mann Whitney test. (D) Circos plot showing location of nucleotide mutations from the second infection relative to other viruses circulating at the same time in the same geographic region. Only rare mutations present in $<1 \%$ of contemporaneous community sequences are shown. (E) Number of rare nucleotide polymorphisms at each time point relative 406 to circulating sequences in the community. $\mathrm{P}=0.26$, Wilcoxon matched-pairs signed rank test. 407 ORF: open reading frame, S: Spike, E: Envelope, M: Membrane, N: Nucleocapsid.

Figure 3. SARS-CoV-2 mutation location and evolutionary rate in the persistent COVID-19 cases. (A) Nucleotide (NT) substitution frequency pooled across all persistent cases for each SARS-CoV-2 gene. Dashed line indicates global substitution frequency across the whole

411 genome. Substitution frequency for each gene was compared to the substitution frequency in 412 the rest of the genome using a Fisher's exact test. P-values were corrected for multiple 413 comparisons using the Bonferroni correction. ${ }^{*}<0.05,{ }^{* *}<0.01$ and ${ }^{* * *}<0.001$ (B) Nucleotide 
medRxiv preprint doi: https://doi.org/10.1101/2021.03.02.21252750; this version posted April 17, 2021. The copyright holder for this preprint (which was not certified by peer review) is the author/funder, who has granted medRxiv a license to display the preprint in perpetuity. It is made available under a CC-BY-NC-ND 4.0 International license .

414 changes in samples taken prior to convalescent plasma or monoclonal antibody treatment

415 relative to first sampled sequence in each persistently infected patient. Regression line and 95\%

416 confidence bands are shown. Purple dash-dotted line is global rate estimate obtained from

417 NextStrain. (C) Nucleotide changes in samples taken after convalescent plasma or monoclonal

418 antibody treatment relative to last sample taken prior to treatment in each persistently infected

419 patient. Regression line and 95\% confidence bands are shown. (D) Substitution rate (nucleotide

420 substitutions per site per year) of sampled global SARS-CoV-2 sequences relative to persistent

421 patients based on Markov chain Monte Carlo time-measured phylogenetic reconstruction. Box

422 plots show median and interquartile ranges of estimated substitution rates. The mean, median,

423 and 95\% highest posterior density (HPD) interval can be found in Supplemental Table 4. 
Table 1. Reinfection cases

\begin{tabular}{|c|c|c|c|c|c|c|c|c|c|}
\hline Patient & Authors & $\begin{array}{l}\text { Publication/P } \\
\text { re-print } \\
\text { server (year) }\end{array}$ & Age & Sex & Comorbidities & $\begin{array}{l}\text { Time } \\
\text { between } \\
\text { infections } \\
\text { (days) }\end{array}$ & $\begin{array}{l}\text { Second } \\
\text { infection } \\
\text { severity }\end{array}$ & $\begin{array}{l}\text { First } \\
\text { infection } \\
\text { clade }\end{array}$ & $\begin{array}{l}\text { Second } \\
\text { infection } \\
\text { clade }\end{array}$ \\
\hline Re1 & $\begin{array}{l}\text { Selhorst, et } \\
\text { al. }\end{array}$ & $\begin{array}{l}\text { Clin. Infect. } \\
\text { Dis. (2020) }\end{array}$ & 39 & $\mathrm{~F}$ & None & 185 & Less & $19 \mathrm{~A}$ & $20 A$ \\
\hline $\operatorname{Re} 2$ & To, et al. & $\begin{array}{l}\text { Clin. Infect. } \\
\text { Dis. (2020) }\end{array}$ & 33 & $\mathrm{M}$ & None & 144 & Less & $19 A$ & $20 E$ \\
\hline Re3 & $\begin{array}{l}\text { Prado-Vivar, } \\
\text { et al. }\end{array}$ & $\begin{array}{l}\text { Lancet Infect. } \\
\text { Dis. (2021) }\end{array}$ & 46 & $\mathrm{M}$ & None & 63 & More & $20 \mathrm{~A}$ & 19B \\
\hline Re4 & Tillett, et al. & $\begin{array}{l}\text { Lancet Infect. } \\
\text { Dis. (2020) }\end{array}$ & 25 & $\mathrm{M}$ & None & 48 & More & $20 C$ & $20 C$ \\
\hline Re5 & $\begin{array}{l}\text { Goldman, et } \\
\text { al. }\end{array}$ & medRxiv & $60-69$ & $\mathrm{~N} / \mathrm{A}$ & $\begin{array}{l}\text { Emphysema, } \\
\text { hypertension }\end{array}$ & 139 & Less & $19 B$ & $20 \mathrm{~A}$ \\
\hline Re6 & $\begin{array}{l}\text { Resende, et } \\
\text { al. }\end{array}$ & Virological & 37 & $\mathrm{~F}$ & None & 116 & Similar & $20 B$ & $20 B$ \\
\hline $\operatorname{Re} 7$ & $\begin{array}{l}\text { Harrington, et } \\
\text { al. }\end{array}$ & $\begin{array}{l}\text { Clin. Infect. } \\
\text { Dis. (2021) }\end{array}$ & 78 & $\mathrm{M}$ & $\begin{array}{l}\text { Diabetic } \\
\text { nephropathy with } \\
\text { hemodialysis, } \\
\text { COPD, sleep apnea, } \\
\text { ischemic heart } \\
\text { disease }\end{array}$ & 250 & More & $19 \mathrm{~A}$ & $\begin{array}{l}20 \mathrm{l} \\
(\mathrm{B} .1 .1 .7)\end{array}$ \\
\hline Re8 & $\begin{array}{l}\text { Van } \\
\text { Elslande, et } \\
\text { al. }\end{array}$ & $\begin{array}{l}\text { Clin. Infect. } \\
\text { Dis. (2021) }\end{array}$ & 51 & $\mathrm{~F}$ & Asthma & 93 & Less & $20 B$ & $19 B$ \\
\hline Re9 & Colson, et al. & $\begin{array}{l}\text { J. Infect. } \\
(2020)\end{array}$ & 70 & $\mathrm{M}$ & None & 105 & Less & $20 \mathrm{~A}$ & 20A.EU2 \\
\hline
\end{tabular}




\begin{tabular}{|c|c|c|c|c|c|c|c|c|c|}
\hline Re10 & $\begin{array}{l}\text { Nonaka, et } \\
\text { al. }\end{array}$ & $\begin{array}{l}\text { Emerg. } \\
\text { Microbes } \\
\text { Infec. }(2021)\end{array}$ & 45 & $\mathrm{~F}$ & None & 147 & More & 20B & $20 \mathrm{~B}$ \\
\hline Re11-1 & \multirow[t]{2}{*}{ Gupta, et al. } & \multirow[t]{2}{*}{$\begin{array}{l}\text { Clin. Infect. } \\
\text { Dis (2020) }\end{array}$} & 25 & $\mathrm{M}$ & None & 108 & $\begin{array}{l}\text { Both } \\
\text { asymptomatic }\end{array}$ & $19 \mathrm{~A}$ & $20 \mathrm{~A}$ \\
\hline Re11-2 & & & 28 & $\mathrm{~F}$ & None & 111 & $\begin{array}{l}\text { Both } \\
\text { asymptomatic }\end{array}$ & $20 \mathrm{~A}$ & $20 \mathrm{~A}$ \\
\hline $\operatorname{Re} 12-1$ & \multirow{2}{*}{$\begin{array}{l}\text { Abu-Raddad, } \\
\text { et al. }\end{array}$} & \multirow{2}{*}{$\begin{array}{l}\text { Clin. Infect. } \\
\text { Dis (2020) }\end{array}$} & $25-29$ & $\mathrm{M}$ & $\mathrm{N} / \mathrm{A}$ & 46 & $\mathrm{~N} / \mathrm{A}$ & $19 \mathrm{~A}$ & $20 \mathrm{~A}$ \\
\hline Re12-2 & & & $40-44$ & $M$ & $\mathrm{~N} / \mathrm{A}$ & 71 & $\mathrm{~N} / \mathrm{A}$ & $19 A$ & $20 \mathrm{~A}$ \\
\hline Re13-1 & \multirow[t]{3}{*}{ Naveca, et al. } & \multirow{3}{*}{$\begin{array}{l}\text { Research } \\
\text { Square }\end{array}$} & 29 & $\mathrm{~N} / \mathrm{A}$ & $\mathrm{N} / \mathrm{A}$ & 281 & Similar & $20 \mathrm{~A}$ & 20J (P.1) \\
\hline Re13-2 & & & 50 & $\mathrm{~N} / \mathrm{A}$ & $\mathrm{N} / \mathrm{A}$ & 153 & Similar & $20 \mathrm{~B}$ & 20J (P.1) \\
\hline Re13-3 & & & 40 & $\mathrm{~F}$ & $\mathrm{~N} / \mathrm{A}$ & 282 & Similar & $20 \mathrm{~A}$ & 20J (P.1) \\
\hline Re14 & Vetter, et al. & $\begin{array}{l}\text { Clin. } \\
\text { Microbiol. } \\
\text { Infec. (2021) }\end{array}$ & 36 & $\mathrm{~F}$ & None & 205 & Similar & $20 \mathrm{~A}$ & 20A.EU2 \\
\hline Re15 & $\begin{array}{l}\text { Kulkarni, et } \\
\text { al. }\end{array}$ & $\begin{array}{l}\text { Clin. Infect. } \\
\text { Dis (2021) }\end{array}$ & 61 & $M$ & None & 44 & More & 20B & $20 \mathrm{~B}$ \\
\hline Re16 & $\begin{array}{l}\text { Adrielle dos } \\
\text { Santos, et al. }\end{array}$ & $\begin{array}{l}\text { J. Infect. } \\
(2021)\end{array}$ & 40 & $\mathrm{~F}$ & $\begin{array}{l}\text { Systemic arterial } \\
\text { hypertension, } \\
\text { obesity }\end{array}$ & 53 & Less severe & $20 \mathrm{~A}$ & $20 \mathrm{~A}$ \\
\hline
\end{tabular}


Table 2. Persistent cases

\begin{tabular}{|c|c|c|c|c|c|c|c|c|c|}
\hline Patient & Case & $\begin{array}{l}\text { Publicatio } \\
\text { n (year) }\end{array}$ & $\begin{array}{l}\mathrm{Ag} \\
\mathrm{e}\end{array}$ & $\begin{array}{l}\mathrm{Se} \\
\mathrm{x}\end{array}$ & Underlying conditions & Immunosupressants & $\begin{array}{l}\text { Antiviral } \\
\text { treatment }\end{array}$ & $\begin{array}{l}\text { Infection } \\
\text { length }\end{array}$ & $\begin{array}{l}\text { Fatal } \\
?\end{array}$ \\
\hline $\mathrm{Pe} 1$ & $\begin{array}{l}\text { Choi, et } \\
\text { al. }\end{array}$ & $\begin{array}{l}\text { New Engl. } \\
\text { J. Med. } \\
(2020)\end{array}$ & 45 & $\mathrm{M}$ & $\begin{array}{l}\text { Antiphospholipid } \\
\text { antibody syndrome }\end{array}$ & $\begin{array}{l}\text { Rituximab, eculizumab, } \\
\text { cyclophosphamide, } \\
\text { corticosteroids }\end{array}$ & $\begin{array}{l}\text { Remdesivir, } \\
\text { casirivimab and } \\
\text { imdevimab }\end{array}$ & 154 & Yes \\
\hline $\mathrm{Pe} 2$ & $\begin{array}{l}\text { Baang, et } \\
\text { al. }\end{array}$ & $\begin{array}{l}\text { J. Infect. } \\
\text { Dis. (2021) }\end{array}$ & 60 & $\mathrm{M}$ & $\begin{array}{l}\text { Refractory mantle cell } \\
\text { lymphoma }\end{array}$ & $\begin{array}{l}\text { CD20 bispecific } \mathrm{Ab}, \mathrm{B}- \\
\text { cell directed } \mathrm{Ab} \text {, } \\
\text { cyclophosphamide, } \\
\text { doxorubicin, prednisone }\end{array}$ & $\begin{array}{l}\text { Remdesivir, } \\
\text { convalescent } \\
\text { plasma }\end{array}$ & 156 & Yes \\
\hline Pe3 & $\begin{array}{l}\text { Avanzato } \\
\text {, et al. }\end{array}$ & Cell (2020) & 71 & $\mathrm{~F}$ & $\begin{array}{l}\text { CLL, acquired } \\
\text { hypogammaglobulinemi } \\
\text { a }\end{array}$ & - & $\begin{array}{l}\text { Convalescent } \\
\text { plasma }\end{array}$ & 156 & No \\
\hline Pe4 & $\begin{array}{l}\text { Kemp, et } \\
\text { al. }\end{array}$ & $\begin{array}{l}\text { Nature } \\
\text { (2021) }\end{array}$ & - & - & $\begin{array}{l}\text { Marginal B cell } \\
\text { lymphoma, } \\
\text { hypogammaglobulinemi } \\
\text { a }\end{array}$ & B-cell depleting therapy & $\begin{array}{l}\text { Remdesivir, } \\
\text { convalescent } \\
\text { plasma }\end{array}$ & 102 & Yes \\
\hline Pe5 & $\begin{array}{l}\text { Tarhini, } \\
\text { et al. }\end{array}$ & $\begin{array}{l}\text { J. Infect. } \\
\text { Dis. (2021) }\end{array}$ & 66 & $\mathrm{M}$ & $\begin{array}{l}\text { HIV, multifocal } \\
\text { leukoencephalopathy } \\
\text { from JC virus }\end{array}$ & - & - & 124 & No \\
\hline Pe6-1 & $\begin{array}{l}\text { Truong, } \\
\text { et al. }\end{array}$ & medRxiv & $<5$ & $\mathrm{~F}$ & B-cell ALL & $\begin{array}{l}\text { Dexamethasone, } \\
\text { vincristine, peg- } \\
\text { asparaginase, } \\
\text { methotrexate, 6-MP, } \\
\text { doxorubicin }\end{array}$ & - & 91 & No \\
\hline Pe6-2 & & & $\begin{array}{l}20- \\
25\end{array}$ & $\mathrm{M}$ & B-cell ALL & $\begin{array}{l}\text { CD-19 directed CAR-T } \\
\text { cell therapy } \\
\text { (tisagenlecleucel), } \\
\text { cylcophosphamide, } \\
\text { fludarabine }\end{array}$ & $\begin{array}{l}\text { Remdesivir, } \\
\text { convalescent } \\
\text { plasma }\end{array}$ & $250+$ & No \\
\hline
\end{tabular}




\begin{tabular}{|l|l|l|l|l|l|l|l|l|}
\hline Pe6-3 & & & $<5$ & M & B-cell ALL & $\begin{array}{l}\text { Cyclophosphamide, } \\
\text { cytarabine, thioguanine, } \\
\text { vincristine, } \\
\text { dexamethasone, } \\
\text { methotrexate, } \\
\text { mercaptopurine }\end{array}$ & 196 & No \\
\hline Pe7 & $\begin{array}{l}\text { Borges, } \\
\text { et al. }\end{array}$ & Virological & 61 & $\mathrm{~F}$ & $\begin{array}{l}\text { Diffuse large B cell } \\
\text { lymphoma }\end{array}$ & $\begin{array}{l}\text { Chemotherapy } \\
\text { (unspecified), } \\
\text { methotrexate, } \\
\text { corticosteroids }\end{array}$ & Remdesivir & 197 \\
\hline
\end{tabular}

ALL: acute lymphoblastic leukemia, CLL: chronic lymphocytic leukemia, RDV: remdesivir, CP: convalescent plasma, Ab: antibody 
Figure 1

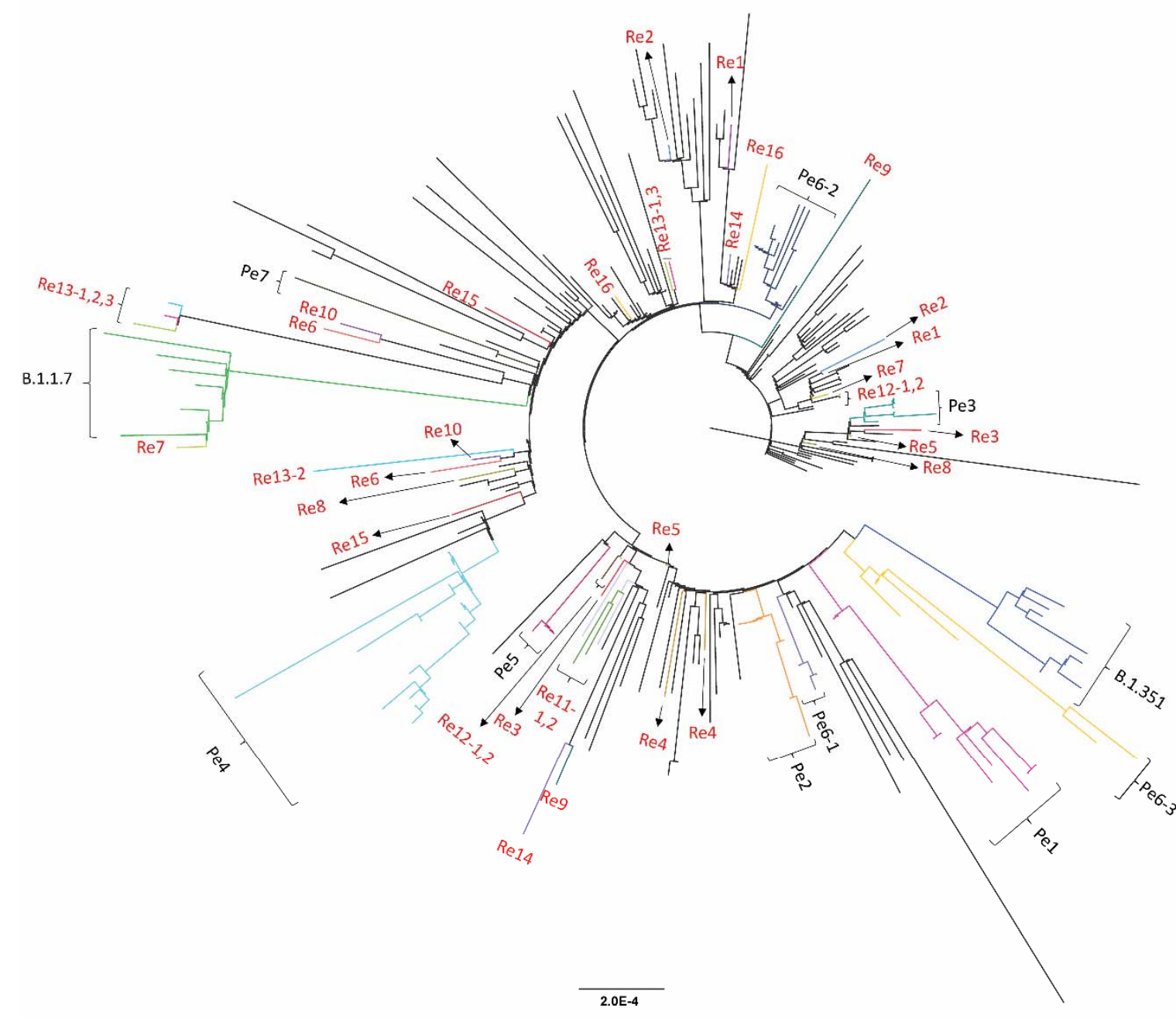

콩

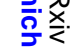

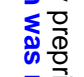

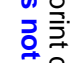

율을.

棓言

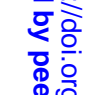

$\mp \stackrel{\Phi}{\stackrel{0}{0}}$

क 市。

Variants of concern
Ba.1.
s.1.

- 0.1 .1 .7

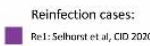

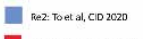

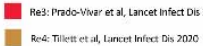

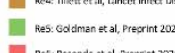

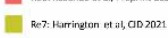

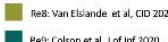

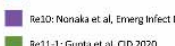

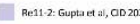

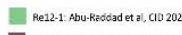

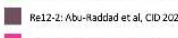

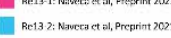

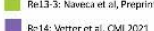

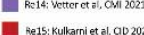

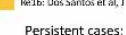

Persistent cases:

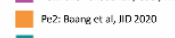

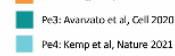

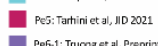

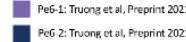

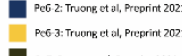

이올오

क ज N

产志

흠이

क

응을 엄

๙

0 工

ए

崖交.

之志心

Z음

휴윰ㅇㅁㅇ

吾需㖞

옥 윰

흘.

ఏำ.

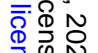

क ल

( $\overrightarrow{0}$

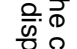

인융

호을

웡 흥

골

궁음

$\frac{\mathrm{O}}{\mathrm{O}} \mathrm{F}$

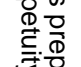

굴. 
Figure 2
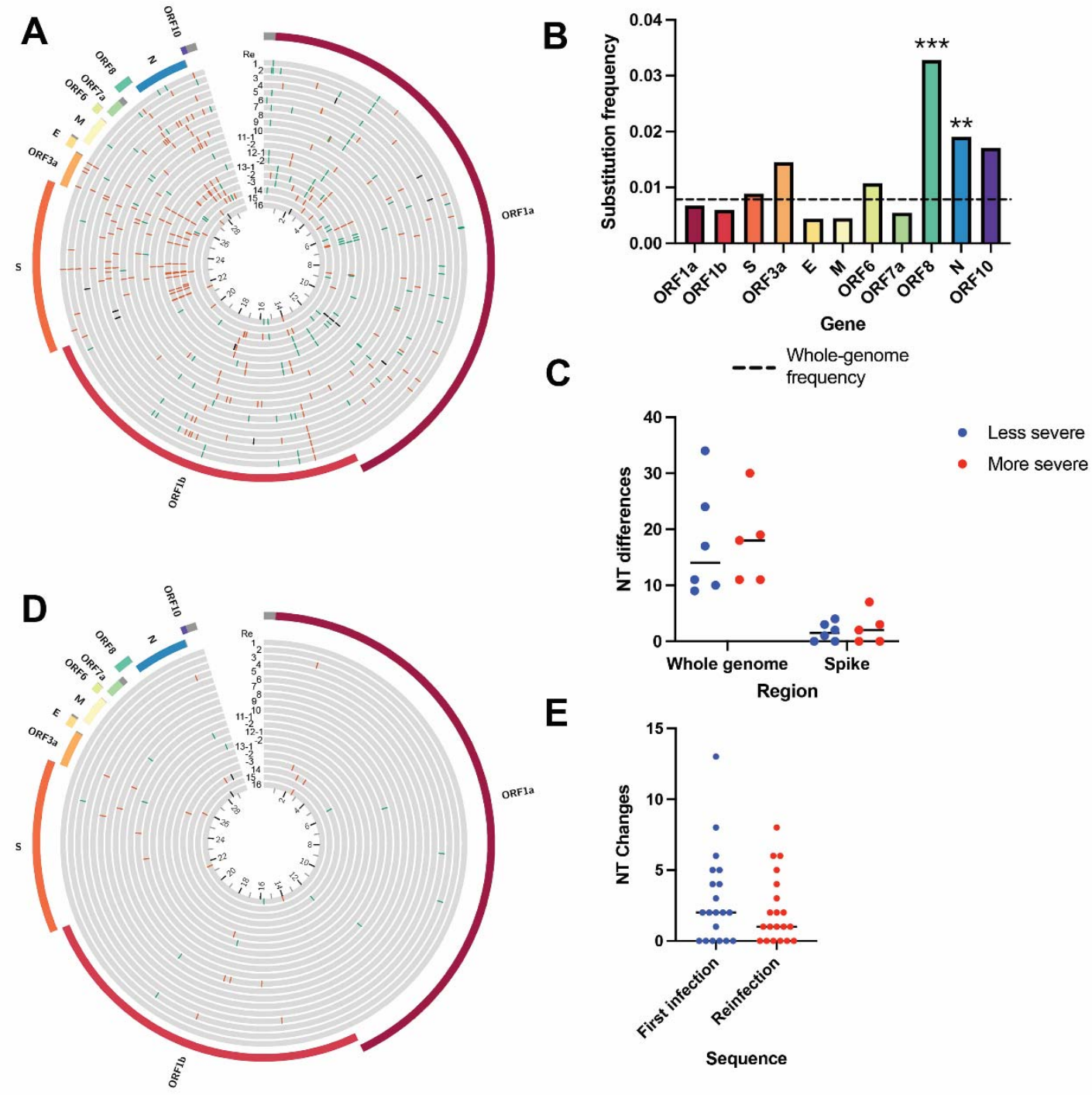
Figure 3

A
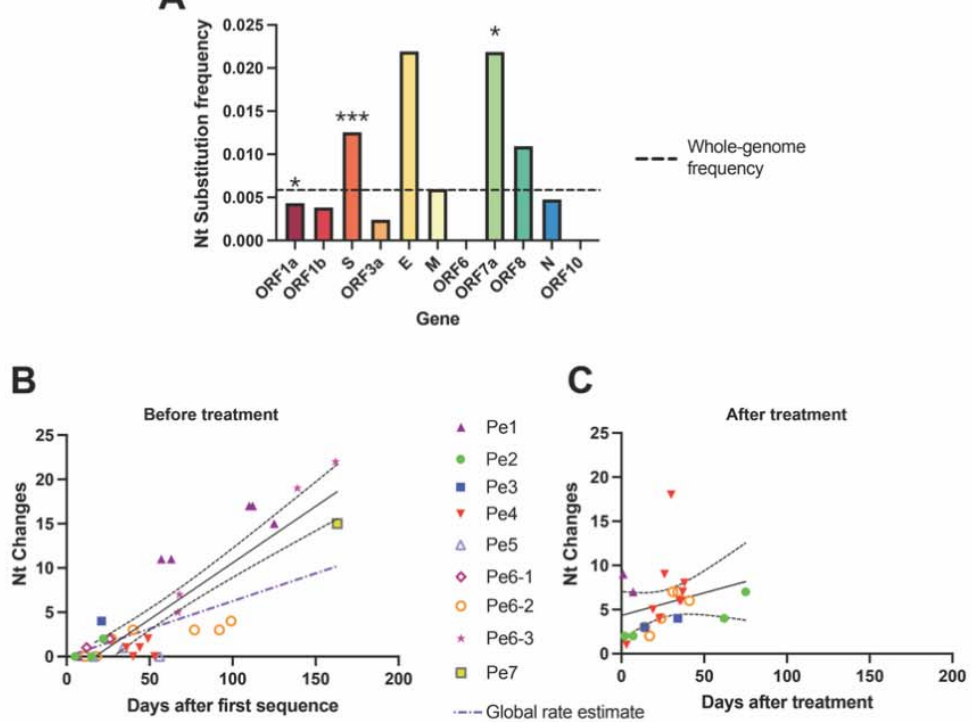

D

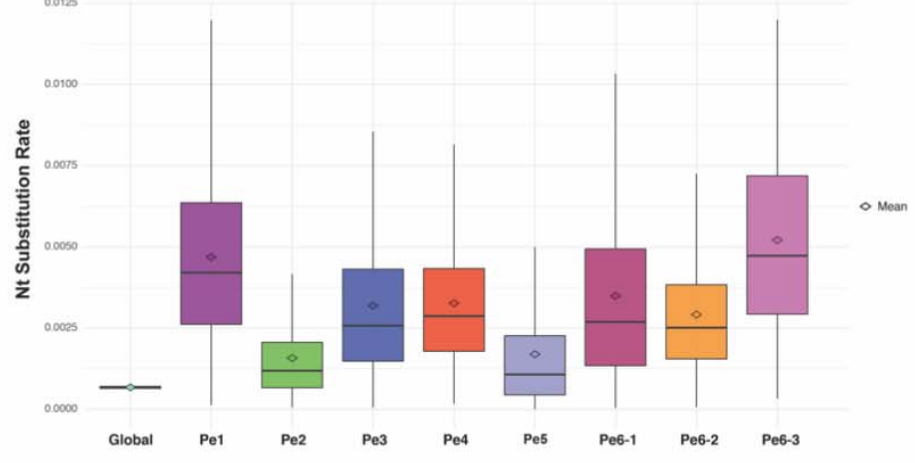

